\title{
MATHEMATICAL MODELING OF THIN LAYER DRYING OF SALTED YELLOWTAIL FISH UNDER OPEN SUN AND IN GREENHOUSE DRYER
}

\author{
Pujianto Andreas*, Sidhi Sigit Deddy Purnomo, Nurfauzi Akhmad \\ Politeknik Kelautan and Perikanan Sorong, Indonesia \\ *E-mail: a.pujianto@polikpsorong.ac.id
}

\begin{abstract}
The thin layer dryer model was used to describe the characteristics of changes in water content of salted yellowtail dried under the open sun and by using a greenhouse dryer. Thirteen different thin layer dryer models were used to predict fish water content values. The results of the conducted experiments validated the values. From the results of modeling for open sun drying, it was discovered that Modified Henderson and Pabis were the most suitable models to be used. While for drying using greenhouse dryers, it was suitable to use the Diffusion Approach model and Verma et al. From the performance of modeling indicator, it was shown that the value of the correlation coefficient $(R)$ approaching 1, where the mean square of deviation between experimental, predicted values and root mean square error analysis (RMSE) have infinitesimal values.
\end{abstract}

\section{KEY WORDS}

Thin layer drying model, open sun drying, greenhouse dryer, yellowtail fish.

Fish meat contains a good source of protein (15-20\%), vitamins, carbohydrates, and other substances that are soluble in water (Sobukola \& Olatunde, 2011). Moreover, fresh fish products contain $80 \%$ moisture content (Darvishi, Azadbakht, Rezaeiasl, \& Farhang, 2013). It makes the fish very quickly experience quality degradation. Fish is one type of food that contains water, where the water content in fish must be discarded. If fresh fish is not used directly or not processed into finished products, the fish will undergo a decay process (Sidhi, Pujianto, Prasetyo, \& Muhfizar, 2017). Proper handling of fish is needed so that the quality can be maintained. There are various methods of preserving fish such as fumigation, drying, salting, and freezing. The drying of food products is an important thing to increase resistance on degradation due to water activity reduction (Bellagha, Amami, Farhat, \& Kechaou, 2002).

Drying and salting fish is a technique that has long been used for preserving fish (Boudhrioua, Djendoubi, Bellagha, \& Kechaou, 2009). In some developing countries, dried salted fish is one source of protein at low prices (Bellagha, Sahli, Farhat, Kechaou, \& Glenza, 2007). Fish drying can be done by using traditional methods, namely open sun drying or solar drying using hot air. The open sun drying process has many disadvantages including long drying times, requires a large area, the quality of fish decreases due to dust, prone to animal disturbances such as flies, chickens, cats, and dogs and requires considerable labor (Setyoko \& Darmanto, 2012). Comparing to open sun drying, the use of greenhouse dryers leads to reducing drying time up to $50 \%$ and a significant increase in product quality in terms of color, texture, and taste (Das \& Tiwari, 2008). Solar dryer for fish products has been developed in several studies. Bala and Mondol (2001) investigated solar tunnel dryers to dry silver jewfish. Sengar, Khandetod, and Mohod (2009) examined solar dryers with the cost of dry shrimp (Kolambi). (Akinola, Akinyemi, \& Bolaji, 2006)Akinola, Akinyemi, and Bolaji (2006) conducted a study of traditional drying and solar drying systems for fish in Nigeria. Handoyo, Kristanto, and Alwi (2003) developed an indirect solar dryer system with forced ventilation open circuit as a solar fish dryer. (Bintang, Pongoh, \& Onibala, 2013)Bintang, Pongoh and Onibala (2013) made a solar fish dryer with a loading and unloading system. Fudholi, Ruslan, and Othman (2013) developed a hybrid solar drying system (HSDS) with rotating rack for salted silver jewfish. Sidhi, Pujianto, Prasetyo, and 
Muhfizar (2018) conducted an experimental study of yellowtail fish drying under an active greenhouse dryer.

The thin layer equation describes the overall drying phenomenon, regardless of the control mechanism. This equation has been used to estimate the drying time of some products and to generalize the drying curve (Akpinar \& Bicer, 2008). Several studies have used the thin layer model for the fish drying process. Kituu et al. (2010) used mathematical thin layer models for the Tilapia fish drying process in the solar tunnel dryer. Guan, Wang, Li, and Jiang Guan, Wang, Li, and Jiang (2013) used thin layer modeling for fresh tilapia fillets using hot air convection. Sobukola and Olatunde (2011) conducted thin layer modeling for the drying process of African catfish with different brine concentrations and temperatures. Jain and Pathare (2007) used thin layer modeling for the drying process of shrimp and chelwa fish (Indian minor carp) in open sun drying. Bai, Li, Sun, and Shi (2011) used mathematical modeling for drying fish slices using the electrohydrodynamic (EHD) drying layer method. Darvishi et al. (2013) conducted thin layer modeling for sardine fish dried in microwave heaters.

Yellowtail fish is a type of consumption fish that has essential economic value and is one type of reef fish that lives in warm waters around the Indo Pacific. In this study, yellowtail drying was carried out under open sun drying and greenhouse solar dryer. The mathematical thin layer dryer for drying yellowtail fish has not been done yet. Therefore, this study aims to model salted yellow fish as thin layer dryers under open sun drying and solar greenhouse dryers.

\section{METHODS OF RESEARCH}

Material and Experimental Procedure. The greenhouse dryer shown in Figure 1 has a parabolic roof with paving blocks as a base. The surface area is $6.5 \mathrm{~m}^{2}$, with dimensions of length and width are $3.25 \mathrm{~m} \times 2 \mathrm{~m}$. The greenhouse length sides lead to the north and south in order to suit the movement of the sun. Polyethylene plastic was used for the material of greenhouse cover. The greenhouse framework made of galvanized pipes. Six 12 VDC exhaust fans with 100 WP solar cell as the electric energy supplier are used to circulate air inside the greenhouse.
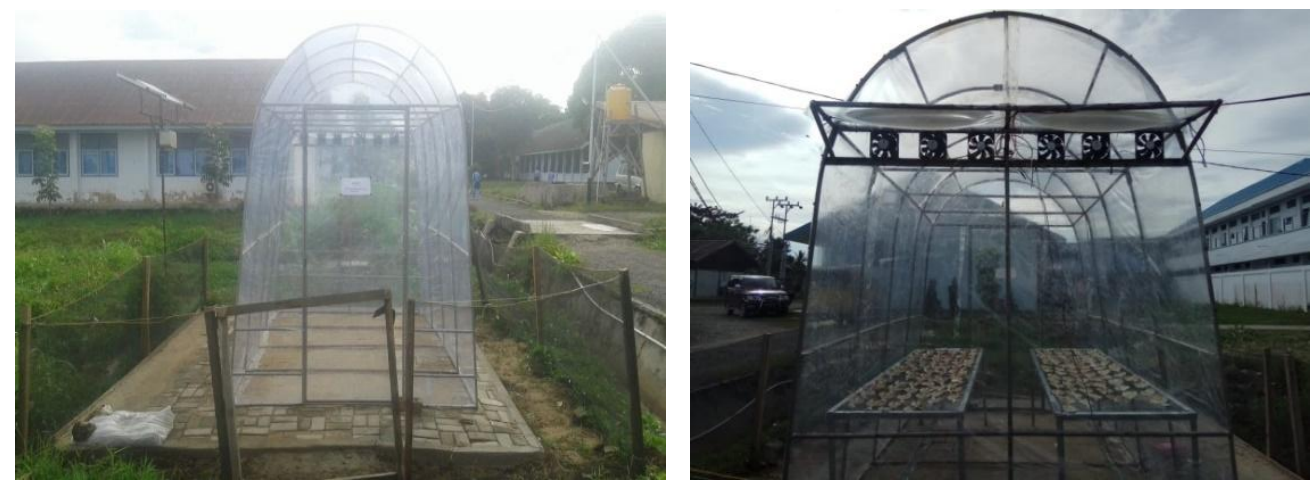

Figure 1 - The appearance of the front and back sides of the greenhouse dryer

The tests were carried out with two methods, i.e., open sun drying and under the greenhouse dryer. The drying was done at Politeknik Kelautan and Perikanan Sorong for three days in December 2017 to reduce the water content of fish products. The yellowtail fish was used in this study. It was dried for 8 hours every day. The fishes were given salt of 0.2 $\mathrm{gr} \mathrm{NaCl} / \mathrm{gr}$ of fish mass on the dry salted method. The mass of fish used during the experiment about $0.3 \mathrm{~kg}$ either for open sun drying or under the greenhouse dryer. The dried fishes for three days were dried further by using the oven for 24 hours at a temperature of $105^{\circ} \mathrm{C}$ (Mujaffar \& Sankat, 2005). The method was done to find out the initial water content of the fish. 
In this study, DHT 22 sensors were used to measure air humidity and temperature both in the environment and inside the greenhouse by using a calibrated data logger microcontroller. The data recording of air humidity and the temperature were set once every hour during the drying process. A digital scale was used to measure the changes of fish mass during the drying process. The fish mass data was manually recorded to measure changes in mass.

Model Thin Layer Dryer. Moisture ratio (MR) of the product shown in Eq. (1). The equation can be simplified to $M / M_{0}$ (Akpinar \& Bicer, 2008; C. Ertekin \& Yaldiz, 2004; Jain \& Pathare, 2007). The dry basis method was used to calculate the moisture ratio equation. $M$ is the moisture content at the time of measurement, $M_{0}$ is the initial moisture content of fish, and $M_{e}$ is the equilibrium moisture content which has a very smaller value than $M$ and $M_{0}$ (Jain \& Pathare, 2007). The thin layer dryer model used to describe the drying process with different moisture ratio model Eq. (5-16) in Table 1.

$$
M R=\frac{M-M_{e}}{M_{0}-M_{e}}(1)
$$

A statistic computer program was used for the regression analysis of the decrease in product moisture ratio, so the models which appropriate to the product drying process can be obtained. The correlation coefficient $(R)$, the mean square of the deviations between the experimental and predicted values $\left(\mathrm{X}^{2}\right)$, and the root mean square error analysis (RMSE) in (Eq. 2-4) were used to determine the goodness of the fit on regression (Akpinar \& Bicer, 2008; Rabha, Muthukumar, \& Somayaji, 2017). The correlation coefficient has a range value between $0-1$. The greater relationship exists between experimental and predicted values were closer to 1 (Can Ertekin \& Firat, 2017). The better the goodness of the fit for regression also shown by the lower values on $x^{2}$ and RMSE (Akpinar \& Bicer, 2008; C. Ertekin \& Yaldiz, 2004).

$$
\begin{gathered}
R^{2}=\frac{\sum_{i=1}^{n}\left(M R_{i}-M R_{p r e, i}\right) \cdot \sum_{i=1}^{n}\left(M R_{i}-M R_{\text {exp }, i}\right)}{\sqrt{\left[\sum_{i=1}^{n}\left(M R_{i}-M R_{\text {pre }, i}\right)^{2}\right] \cdot\left[\sum_{i=1}^{n}\left(M R_{i}-M R_{\text {exp }, i}\right)^{2}\right]}}(2) \\
\mathrm{X}^{2}=\frac{\sum_{i=1}^{n}\left(M R_{\text {exp }, i}-M R_{\text {pre }, i}\right)^{2}}{N-n}(3) \\
R M S E=\left[\frac{1}{N} \sum_{i=1}^{N}\left(M R_{\text {pre }, i}-M R_{\text {exp }, i}\right)^{2}\right]^{1 / 2}
\end{gathered}
$$

\begin{tabular}{|c|c|c|c|}
\hline Model Name & Model & \multicolumn{2}{|c|}{ References } \\
\hline Newton & $M R=\exp (-k t)$ & $\begin{array}{l}\text { Eq. } \\
\text { (5) }\end{array}$ & $\begin{array}{l}\text { Akpinar and Bicer } \\
\text { Ertekin and Yaldiz } \\
\text { Sonmete, Menges, } \\
\text { Sontekin, } \\
\text { and Özcan (2017) }\end{array}$ \\
\hline Page & $M R=\exp \left(-k t^{n}\right)$ & $\begin{array}{l}\text { Eq. } \\
\text { (6) }\end{array}$ & $\begin{array}{l}\text { Ertekin and Firat (2017); } \\
\text { Onwude, Hashim, Janius, } \\
\text { Nawi, and Aband, (2016); } \\
\text { Rabha, Muthukumar, \& } \\
\text { Somayaji (2017) }\end{array}$ \\
\hline Modified Page & $M R=\exp \left[(-k t)^{n}\right]$ & $\begin{array}{l}\text { Eq. } \\
\text { (7) }\end{array}$ & $\begin{array}{l}\text { Arslan and Özcan (2010); } \\
\text { Falade and Solademi (2010); } \\
\text { Guiné, Pinho, and Barroca } \\
\text { (2011) }\end{array}$ \\
\hline Henderson and Pabis & $M R=a \exp (-k t)$ & $\begin{array}{l}\text { Eq. } \\
\text { (8) }\end{array}$ & $\begin{array}{l}\text { Diamante, Ihns, Savage, and } \\
\text { Vanhanen (2010); Doymaz } \\
\text { (2012); Meisami-asl, Rafiee, } \\
\text { Keyhani, and Tabatabaeefar } \\
(2010)\end{array}$ \\
\hline Logarithmic & $M R=a \exp (-k t)+c$ & $\begin{array}{l}\text { Eq. } \\
\text { (9) }\end{array}$ & $\begin{array}{l}\text { Doymaz ( 2011, 2012); Evin ( } \\
\text { 2012) }\end{array}$ \\
\hline
\end{tabular}

Table 1 - Mathematical model for drying curve 


\begin{tabular}{|c|c|c|c|}
\hline Two-term & $M R=a \exp \left(-k_{0} t\right)+b \exp \left(-k_{1} t\right)$ & $\begin{array}{l}\text { Eq. } \\
(10)\end{array}$ & $\begin{array}{l}\text { Erbay and Icier (2010); } \\
\text { Kouchakzadeh and Shafee } \\
\text { (2010); Kumar, Sarkar, and } \\
\text { Sharma (2012) }\end{array}$ \\
\hline Two term exponential & $M R=a \exp (-k t)+(1-a) \exp (-k a t)$ & $\begin{array}{l}\text { Eq. } \\
\text { (11) }\end{array}$ & $\begin{array}{l}\text { Demiray and Tulek } \\
\text { Taheri-Garavand, Rafiee, } \\
\text { and Keyhani (2011); Vijayan, } \\
\text { Arjunan, and Kumar (2016) }\end{array}$ \\
\hline Wang and Singh & $M R=1+a t+b t^{2}$ & $\begin{array}{l}\text { Eq. } \\
\text { (12) }\end{array}$ & $\begin{array}{l}\text { Das Purkayastha, Nath, } \\
\text { Deka, and Mahanta (2013); } \\
\text { Janjai (2012); Taher- } \\
\text { garavand, Rafiee, and } \\
\text { Keyhani (2011) }\end{array}$ \\
\hline Diffusion approach & $M R=a \exp (-k t)+(1-a) \exp (-k b t)$ & $\begin{array}{l}\text { Eq. } \\
\text { (13) }\end{array}$ & $\begin{array}{l}\text { El-Sebaii and Shalaby } \\
\text { (2013); Perea-Flores et al., } \\
\text { (2012); Tahmasebi, Yu, and } \\
\text { Han (2013) }\end{array}$ \\
\hline Modified Henderson and Pabis & $M R=a \exp (-k t)+b \exp (-g t)+c \exp (-h t)$ & $\begin{array}{l}\text { Eq. } \\
\text { (14) }\end{array}$ & $\begin{array}{l}\text { Erbay and Icier (2010a) } \\
\text { Meisami-asl et al. (2010); } \\
\text { Taheri-garavand et al. (2011) }\end{array}$ \\
\hline Verma et al & $M R=a \exp (-k t)+(1-a) \exp (-g t)$ & $\begin{array}{l}\text { Eq. } \\
\text { (15) }\end{array}$ & $\begin{array}{l}\text { Kumar et al. } \\
\text { Meisami-asl et al. } \\
\text { Taheri-Garavand } \\
\text { (2010); } \\
(2011)\end{array}$ \\
\hline Midilli and Kucuk & $M R=a \exp \left(-k t^{n}\right)+b t$ & $\begin{array}{l}\text { Eq. } \\
\text { (16) }\end{array}$ & $\begin{array}{lrr}\text { Akhondi, } & \text { Kazemi, } & \text { and } \\
\text { Maghsoodi, } & \text { (2011); } & \text { Evin } \\
\text { (2012); Liu et al. (2014) } & \end{array}$ \\
\hline Thompson & $t=a \ln (M R)+b(\ln (M R))^{2}$ & $\begin{array}{l}\text { Eq. } \\
\text { (17) }\end{array}$ & $\begin{array}{l}\text { (Akpinar \& Bicer, 2008; } \\
\text { Erbay \& Icier, 2010a; } \\
\text { Pardeshi, Arora, \& Borker, } \\
\text { 2009) }\end{array}$ \\
\hline
\end{tabular}

\section{RESULTS AND DISCUSSION}

In the drying process for three days, as shown in Figure 2, the air temperature in the greenhouse dryer ranges from $32-54^{\circ} \mathrm{C}$. The air temperature in the greenhouse tends to be higher than the ambient air temperature which only ranges from $29.8-39^{\circ} \mathrm{C}$. Unlike the temperature, the value of air relative humidity in the greenhouse tends to be lower compared to ambient relative humidity. The range of air humidity values in the drying greenhouse ranges from $24.90-58.71 \%$, while the air humidity value of the environment ranges from $43.26-82.15 \%$.

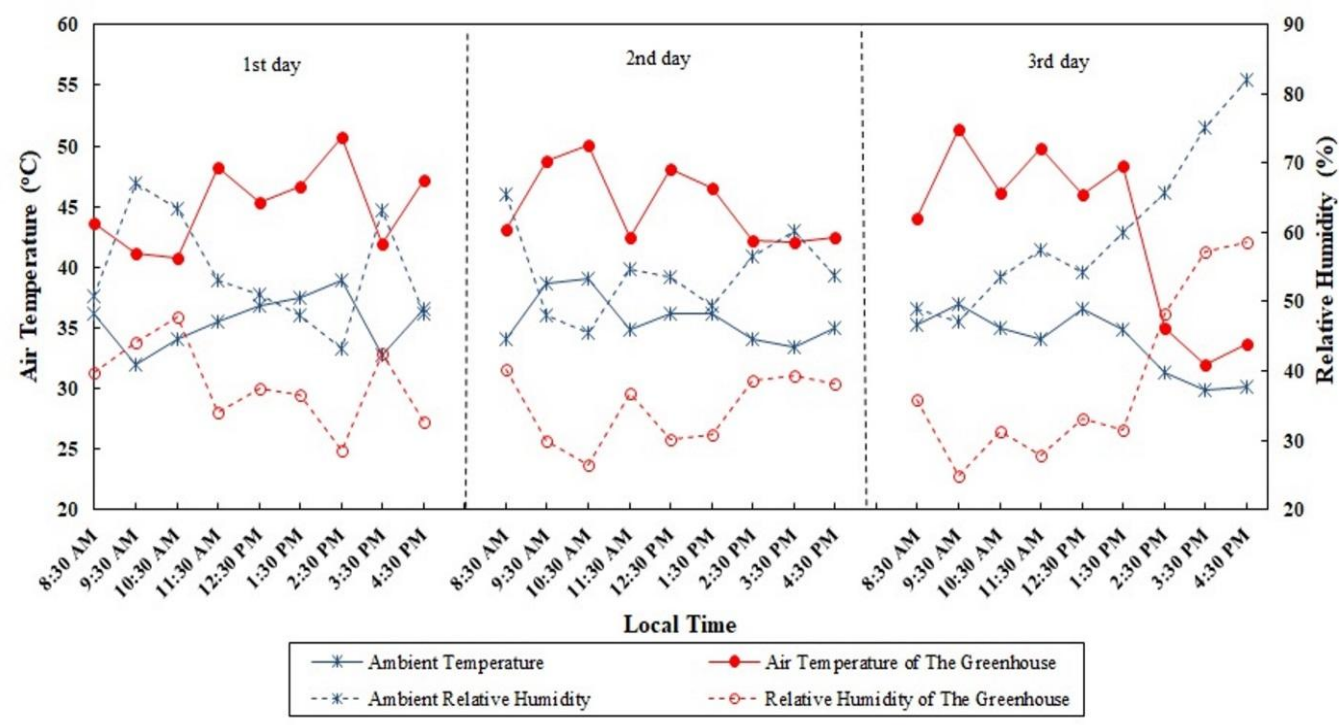

Figure 2 - Temperature and relative humidity of air in ambient and greenhouse condition 
Figure 3 shows the change in water content of fish (dry basis) with two drying methods are with open sun and in the greenhouse dryer. The drying process in the greenhouse dryer looks faster to reduce fish water content compared to the open sun drying method. It proves that the drying rate of fish products in the greenhouse is higher than open sun drying, which is in line with the high air temperature and low relative humidity in it.

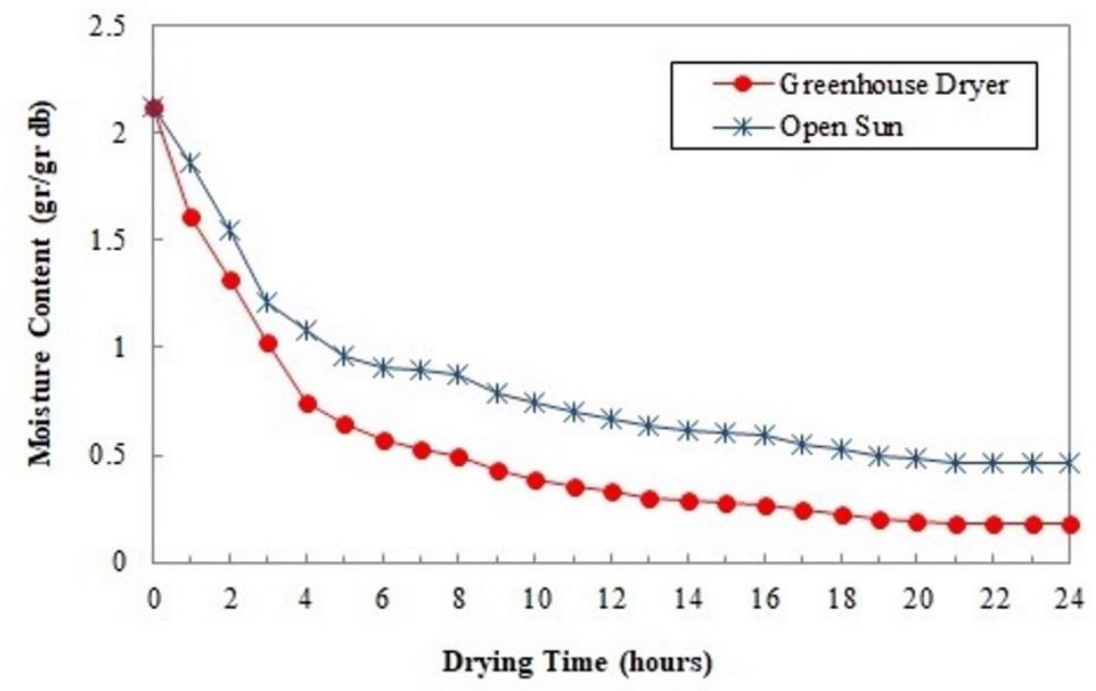

Figure 3 - The moisture content of fish under the open sun and greenhouse dryer for the drying process

Moisture ratio data from experimental results and calculations using thin layer drier modeling was processed using a statistic program on the computer. Each thin layer model was evaluated using the correlation coefficient $(R)$, the mean square of predicted and predicted values $\left(X^{2}\right)$, and the root means square error analysis (RMSE) in (Eq. 2-4). The results of statistic computer program analysis obtained shown in Tables 2 and 3. The suitable model for describes open sun drying of yellowtail fish with dry salting method of 0.2 $\mathrm{gr} \mathrm{NaCl} / \mathrm{gr}$ mass of fish as shown in Table 2 is Modified Henderson and Pabis model, where the value $R=0.9934, x^{2}=0.00053$, and $R M S E=0.01896$. Unlike open sun drying, the drying process in the greenhouse dryer has two of the most suitable model which are Diffusion approach and Verma et al. as shown in Table 3. The value of $R=0.9975, x^{2}=$ 0.0002 , and RMSE $=0.0121$ for both models have the same value even though the constants in the two equations are different.

Table 2 - Moisture Ratio (MR) modeling according to drying time for open sun drying of yellowtail fish

\begin{tabular}{|c|c|c|c|c|c|}
\hline No & Model Name & Model Constants & $\mathrm{R}$ & $x^{2}$ & RMSE \\
\hline 1 & Newton & $\mathrm{k}=0.09865$ & 0.8017 & 0.00892 & 0.09244 \\
\hline 2 & Page & $\mathrm{k}=0.2699, \mathrm{n}=0.577$ & 0.9738 & 0.00129 & 0.03430 \\
\hline 3 & Modified Page & $\mathrm{k}=0.3164, \mathrm{n}=0.3118$ & 0.8017 & 0.00977 & 0.09443 \\
\hline 4 & Henderson and Pabis & $\mathrm{a}=0.8264, \mathrm{k}=0.07667$ & 0.8828 & 0.00578 & 0.07262 \\
\hline 5 & Logarithmic & $\mathrm{a}=0.7526, \mathrm{k}=0.2187, \mathrm{c}=0.2366$ & 0.9831 & 0.00092 & 0.02816 \\
\hline 6 & Two-term & $\begin{array}{l}a=0.5639, k_{0}=0.3736, b=0.4608 \\
k_{1}=0.03364\end{array}$ & 0.9930 & 0.00043 & 0.01856 \\
\hline 7 & Two term exponential & $a=0.2087, k=0,3726$ & 0.9010 & 0.00488 & 0.06672 \\
\hline 8 & Wang and Singh & $a=-0.09346, b=0.002704$ & 0.8533 & 0.00729 & 0.08158 \\
\hline 9 & Diffusion approach & $a=0.5505, k=0.3477, b=0.09322$ & 0.9923 & 0.00042 & 0.01905 \\
\hline 10 & Modified Henderson and Pabis & $\begin{array}{l}\mathrm{a}=-157.5, \mathrm{k}=1.25, \mathrm{~b}=0.561 \\
\mathrm{~g}=0.04468, \mathrm{c}=157.9, \mathrm{~h}=1.244\end{array}$ & 0.9934 & 0.00053 & 0.01896 \\
\hline 11 & Verma et al & $\mathrm{a}=0.4495, \mathrm{k}=0.03241, \mathrm{~g}=0.3477$ & 0.9923 & 0.00042 & 0.01905 \\
\hline 12 & Midilli and Kucuk & $\begin{array}{l}a=1.022, k=0.2438, n=0.7235 \\
b=0.005663\end{array}$ & 0.9851 & 0.00090 & 0.02707 \\
\hline 13 & Thompson & $a=0.7647, b=-0.1236$ & 0.8017 & 0.01079 & 0.09655 \\
\hline
\end{tabular}


Table 3 - Moisture Ratio (MR) modeling according to drying time for drying of yellowtail fish in greenhouse dryer

\begin{tabular}{lllrrr}
\hline No & Model Name & Model Constants & $\mathrm{R}$ & $\mathrm{x}^{2}$ & $\mathrm{RMSE}$ \\
\hline 1 & Newton & $\mathrm{k}=0.192$ & 0.9195 & 0.0046 & 0.0663 \\
\hline 2 & Page & $\mathrm{k}=0.3629, \mathrm{n}=0.6554$ & 0.9855 & 0.0009 & 0.0286 \\
\hline 3 & Modified Page & $\mathrm{k}=0.4214, \mathrm{n}=0.4556$ & 0.9195 & 0.0050 & 0.0677 \\
\hline 4 & Henderson and Pabis & $\mathrm{a}=0.8821, \mathrm{k}=0.1641$ & 0.9369 & 0.0039 & 0.0599 \\
\hline 5 & Logarithmic & $\mathrm{a}=0.8771, \mathrm{k}=0.2746, \mathrm{c}=0.1043$ & 0.9928 & 0.0005 & 0.0206 \\
\hline 6 & Two-term & $\mathrm{a}=0.275, \mathrm{k}=0.05235, \mathrm{~b}=0.7299$, & 0.9975 & 0.0002 & 0.0124 \\
& & $\mathrm{k}=0.3774$ & & & \\
\hline 7 & Two term exponential & $\mathrm{a}=0.2745, \mathrm{k}=0.5257$ & 0.9607 & 0.0024 & 0.0472 \\
\hline 8 & Wang and Singh & $\mathrm{a}=-0.1196, \mathrm{~b}=0.003641$ & 0.7789 & 0.0139 & 0.1125 \\
\hline 9 & Diffusion approach & $\mathrm{a}=0.7282, \mathrm{k}=0.3728, \mathrm{~b}=0.1388$ & 0.9975 & 0.0002 & 0.0121 \\
\hline 10 & Modified Henderson and Pabis & $\mathrm{a}=0.6915, \mathrm{k}=0.4047, \mathrm{~b}=0.0003735$, & 0.9974 & 0.0003 & 0.0133 \\
& & $\mathrm{~g}=-0.1177, \mathrm{c}=0.3153, \mathrm{~h}=0.06197$ & & & \\
\hline 11 & Verma et al & $\mathrm{a}=0.7282, \mathrm{k}=0.3728, \mathrm{~g}=0.05175$ & 0.9975 & 0.0002 & 0.0121 \\
\hline 12 & Midilli and Kucuk & $\mathrm{a}=1.011, \mathrm{k}=0.3234, \mathrm{n}=0.7832$, & 0.9938 & 0.0005 & 0.0195 \\
& & $\mathrm{~b}=0.003153$ & & & \\
\hline 13 & Thompson & $\mathrm{a}=-0.2864, \mathrm{~b}=0.33$ & 0.9196 & 0.0056 & 0.0692 \\
\hline
\end{tabular}

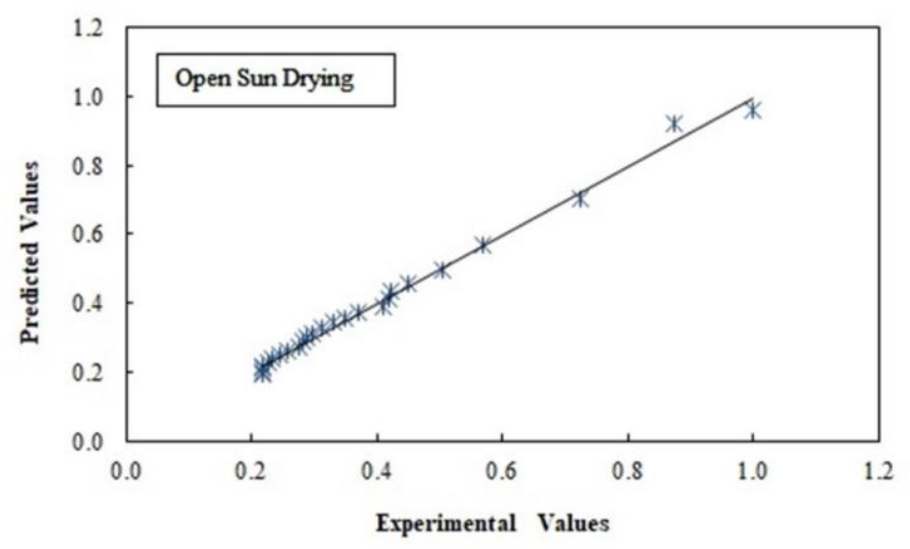

Figure 4 - Comparison of experimental and predicted moisture ratio (MR) by the resulting Modified Henderson and Pabis model in open sun drying

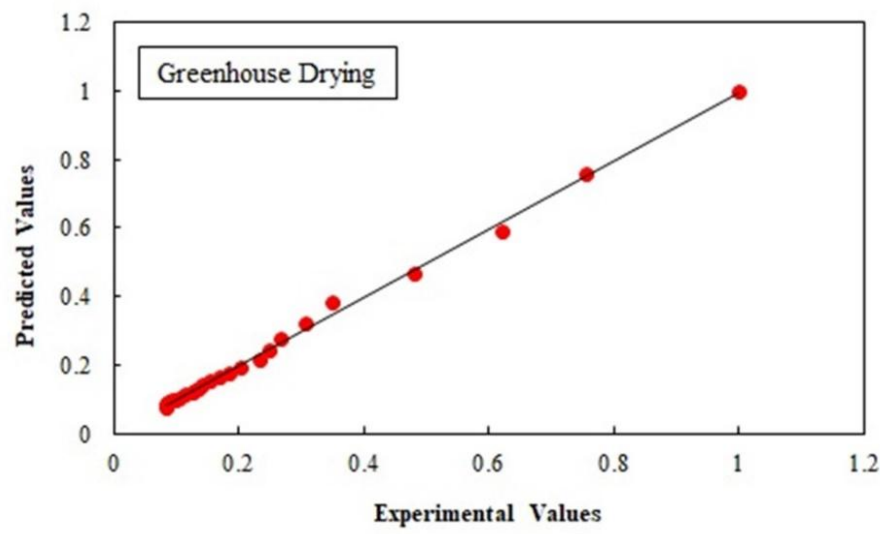

Figure 5 - Comparison of experimental and predicted moisture ratio (MR) by the resulting Diffusion approach model in greenhouse dryer

The modeling results in the drying of yellowtail fish with open sun and drying greenhouses were validated using the results of each experiment. Figures 4 and 5 shows a comparison between predictive values from modeling that match the experimental results for both drying methods. This is evidenced by the experimental data indicated by an asterisk (figure 4) or a circle (figure 5) generally around a straight line which is predictive data from modeling. 


\section{CONCLUSION}

Modeling of thin layer dryer in this study was used to model the drying process of salted yellowtail fish ( $0.2 \mathrm{gr} \mathrm{NaCl} / \mathrm{gr}$ of fish mass) in the open sun and greenhouse dryer. Thirteen models were used to describe changes in moisture content characteristics in both drying methods. Modified Henderson and Pabis is a suitable model to describe the drying process with an open sun with a value of $R=0.9934, x^{2}=0.00053$, and $R M S E=0.01896$. Diffusion approach and Verma et al. are two suitable models describing the drying process in a greenhouse dryer with values $R=0.9975, x^{2}=0.0002$, and R.MSE $=0.0121$.

\section{REFERENCES}

1. Akhondi, E., Kazemi, A., \& Maghsoodi, V. (2011). Determination of a suitable thin layer drying curve model for saffron (Crocus sativus $L$ ) stigmas in an infrared dryer. Scientia Iranica, 18(6), 1397-1401. https://doi.org/10.1016/j.scient.2011.08.014.

2. Akinola, O. A., Akinyemi, A. A., \& Bolaji, B. O. (2006). Evaluation of Traditional and Solar Fish Drying Systems Towards Enhancing Fish Storage and Preservation in Nigeria (Abeokuta Local Governments as Case Study). Journal of Fisheries International, 44-49.

3. Akpinar, E. K., \& Bicer, Y. (2008). Mathematical modelling of thin layer drying process of long green pepper in solar dryer and under open sun. Energy Conversion and Management, 49(6), 1367-1375. https://doi.org/10.1016/j.enconman.2008.01.004.

4. Arslan, D., \& Özcan, M. M. (2010). Study the effect of sun, oven and microwave drying on quality of onion slices. LWT - Food Science and Technology, 43(7), 1121-1127. https://doi.org/10.1016/j.Iwt.2010.02.019.

5. Bai, Y., Li, X., Sun, Y., \& Shi, H. (2011). Thin layer electrohydrodynamic (EHD) drying and mathematical modeling of fish. International Journal of Applied Electromagnetics and Mechanics. https://doi.org/10.3233/JAE-2011-1361.

6. Bala, B. K., \& Mondol, M. R. A. (2001). Experimental investigation on solar drying of fish using solar tunnel dryer. Drying Technology. https://doi.org/10.1081/DRT-100102915.

7. Bellagha, S., Amami, E., Farhat, A., \& Kechaou, N. (2002). Drying kinetics and characteristic drying curve of lightly salted sardine (Sardinella aurita). Drying Technology. https://doi.org/10.1081/DRT-120005866.

8. Bellagha, S., Sahli, A., Farhat, A., Kechaou, N., \& Glenza, A. (2007). Studies on salting and drying of sardine (Sardinella aurita): Experimental kinetics and modeling. Journal of Food Engineering, 78(3), 947-952. https://doi.org/10.1016/j.jfoodeng.2005.12.008.

9. Bintang, Y. M., Pongoh, J., \& Onibala, D. H. (2013). Konstruksi And Kapasitas Alat Pengering Ikan Tenaga Surya Sistem Bongkar-Pasang. Jurnal Media Teknologi Hasil Perikanan.

10. Boudhrioua, N., Djendoubi, N., Bellagha, S., \& Kechaou, N. (2009). Study of moisture and salt transfers during salting of sardine fillets. Journal of Food Engineering. https://doi.org/10.1016/j.jfoodeng.2009.03.005.

11. Darvishi, H., Azadbakht, M., Rezaeiasl, A., \& Farhang, A. (2013). Drying characteristics of sardine fish dried with microwave heating. Journal of the Saudi Society of Agricultural Sciences, 12(2), 121-127. https://doi.org/10.1016/j.jssas.2012.09.002.

12. Das Purkayastha, M., Nath, A., Deka, B. C., \& Mahanta, C. L. (2013). Thin layer drying of tomato slices. Journal of Food Science and Technology, 50(4), 642-653. https://doi.org/10.1007/s13197-011-0397-x.

13. Das, T., \& Tiwari, G. N. (2008). Heat and mass transfer of greenhouse fish drying under forced convection mode. International Journal of Agricultural Research. https://doi.org/10.3923/ijar.2008.69.76.

14. Demiray, E., \& Tulek, Y. (2012). Thin-layer drying of tomato (Lycopersicum esculentum Mill. cv. Rio Grande) slices in a convective hot air dryer. Heat and Mass Transfer/Waerme- Und Stoffuebertragung, 48(5), 841-847. https://doi.org/10.1007/s00231-011-0942-1.

15. Diamante, L. M., Ihns, R., Savage, G. P., \& Vanhanen, L. (2010). A new mathematical 
model for thin layer drying of fruits. International Journal of Food Science and Technology, 45(9), 1956-1962. https://doi.org/10.1111/j.1365-2621.2010.02345.x.

16. Doymaz, I. (2011). Thin-layer drying characteristics of sweet potato slices and mathematical modelling. Heat and Mass Transfer/Waerme- Und Stoffuebertragung, 47(3), 277-285. https://doi.org/10.1007/s00231-010-0722-3.

17. Doymaz, I. (2012). Evaluation of some thin-layer drying models of persimmon slices (Diospyros kaki L.). Energy Conversion and Management, 56, 199-205. https://doi.org/10.1016/j.enconman.2011.11.027.

18. El-Sebaii, A. A., \& Shalaby, S. M. (2013). Experimental investigation of an indirect-mode forced convection solar dryer for drying thymus and mint. Energy Conversion and Management, 74, 109-116. https://doi.org/10.1016/j.enconman.2013.05.006.

19. Erbay, Z., \& Icier, F. (2010a). A review of thin layer drying of foods: Theory, modeling, and experimental results. Critical Reviews in Food Science and Nutrition, 50(5), 441464. https://doi.org/10.1080/10408390802437063.

20. Erbay, Z., \& Icier, F. (2010b). Thin-layer drying behaviors of olive leaves (Olea europaea L.). Journal of Food Process Engineering, 33(2), 287-308. https://doi.org/10.1111/j.17454530.2008.00275.x.

21. Ertekin, C., \& Yaldiz, O. (2004). Drying of eggplant and selection of a suitable thin layer drying model. Journal of Food Engineering, 63(3), 349-359. https://doi.org/10.1016/j.jfoodeng.2003.08.007.

22. Ertekin, Can, \& Firat, M. Z. (2017). A comprehensive review of thin-layer drying models used in agricultural products. Critical Reviews in Food Science and Nutrition, 57(4), 701717. https://doi.org/10.1080/10408398.2014.910493.

23. Evin, D. (2012). Thin layer drying kinetics of Gundelia tournefortii L. Food and Bioproducts Processing, 90(2), 323-332. https://doi.org/10.1016/j.fbp.2011.07.002.

24. Falade, K. O., \& Solademi, O. J. (2010). Modelling of air drying of fresh and blanched sweet potato slices. International Journal of Food Science and Technology, 45(2), 278288. https://doi.org/10.1111/j.1365-2621.2009.02133.x.

25. Fudholi, A., Ruslan, M. H., \& Othman, M. Y. (2013). Energy Consumption of Hybrid Solar Drying System ( HSDS ) with Rotating Rack for Salted Silver Jewfish, (April), 294-298.

26. Guan, Z., Wang, X., Li, M., \& Jiang, X. (2013). Mathematical modeling on hot air drying of thin layer fresh tilapia fillets. Polish Journal of Food and Nutrition Sciences. https://doi.org/10.2478/v10222-012-0065-5.

27. Guiné, R. P. F., Pinho, S., \& Barroca, M. J. (2011). Study of the convective drying of pumpkin (Cucurbita maxima). Food and Bioproducts Processing, 89(4), 422-428. https://doi.org/10.1016/j.fbp.2010.09.001.

28. Handoyo, E. A., Kristanto, P., \& Alwi, S. (2003). Sistem Pengering Ikan Bertenaga Surya.

29. Jain, D., \& Pathare, P. B. (2007). Study the drying kinetics of open sun drying of fish. Journal of Food Engineering, 78(4), 1315-1319. https://doi.org/10.1016/j.jfoodeng.2005.12.044.

30. Janjai, S. (2012). A greenhouse type solar dryer for small-scale dried food industries: Development and dissemination. International Journal of Energy and Environment, 3(3), 383-398.

31. Kituu, G. M., Shitanda, D., Kanali, C. L., Mailutha, J. T., Njoroge, C. K., Wainaina, J. K., \& Silayo, V. K. (2010). Thin layer drying model for simulating the drying of Tilapia fish (Oreochromis niloticus) in a solar tunnel dryer. Journal of Food Engineering. https://doi.org/10.1016/j.jfoodeng.2010.01.009.

32. Kouchakzadeh, A., \& Shafeei, S. (2010). Modeling of microwave-convective drying of pistachios. Energy Conversion and Management, 51(10), 2012-2015. https://doi.org/10.1016/j.enconman.2010.02.034.

33. Kumar, N., Sarkar, B. C., \& Sharma, H. K. (2012). Mathematical modelling of thin layer hot air drying of carrot pomace. Journal of Food Science and Technology, 49(1), 33-41. https://doi.org/10.1007/s13197-011-0266-7.

34. Liu, J.-Z., Cheng, J., Zhu, J.-F., Cen, K.-F., Zhou, J.-H., \& Wu, J.-H. (2014). Thin-layer 
drying characteristics and modeling of Ximeng lignite under microwave irradiation. Fuel Processing Technology, 130, 62-70. https://doi.org/10.1016/j.fuproc.2014.09.033.

35. Meisami-asl, E., Rafiee, S., Keyhani, A., \& Tabatabaeefar, A. (2010). Determination of suitable thin layer drying curve model for apple slices (variety-Golab). Plant OMICS, 3(3), 103-108.

36. Mujaffar, S., \& Sankat, C. K. (2005). The air drying behaviour of shark fillets. Canadian Biosystems Engineering / Le Genie Des Biosystems Au Canada, 47(June).

37. Onwude, D. I., Hashim, N., Janius, R. B., Nawi, N. M., \& Aband, K. (2016). Modeling the Thin-Layer Drying of Fruits and Vegetables: A Review. Comprehensive Reviews in Food Science and Food Safety, 15(3), 599-618. https://doi.org/10.1111/1541-4337.12196.

38. Pardeshi, I. L., Arora, S., \& Borker, P. A. (2009). Thin-layer drying of green peas and selection of a suitable thin-layer drying model. Drying Technology, 27(2), 288-295. https://doi.org/10.1080/07373930802606451.

39. Perea-Flores, M. J., Garibay-Febles, V., Chanona-Pérez, J. J., Calderón-Domínguez, G., Méndez-Méndez, J. V., Palacios-González, E., \& Gutiérrez-López, G. F. (2012). Mathematical modelling of castor oil seeds (Ricinus communis) drying kinetics in fluidized bed at high temperatures. Industrial Crops and Products, 38(1), 64-71. https://doi.org/10.1016/j.indcrop.2012.01.008.

40. Rabha, D. K., Muthukumar, P., \& Somayaji, C. (2017). Experimental investigation of thin layer drying kinetics of ghost chilli pepper (Capsicum Chinense Jacq.) dried in a forced convection solar tunnel dryer. Renewable Energy, 105, 583-589. https://doi.org/10.1016/j.renene.2016.12.091.

41. Sengar, S. H., Khandetod, Y. P., \& Mohod, A. G. (2009). Low cost solar dryer for fish. African Journal of Environmental Science and Technology, 3(9), 265-271.

42. Setyoko, B., \& Darmanto, S. R. (2012). Peningkatan Kualitas Pengeringan Ikan Dengan Sistem Tray Drying. Prosiding SNST Ke_3, 37-42.

43. Sidhi, S.D.P., Pujianto, A., Prasetyo, D., Nurfauzi, A., \& Muhfizar. (2018). EXPERIMENTAL STUDY OF SALTED FISH DRYING UNDER GREENHOUSE DRYER. Russian Journal of Agricultural and Socio-Economic Sciences. https://doi.org/10.18551/rjoas.2018-05.33.

44. Sidhi, Sigit Deddy P, Pujianto, A., Prasetyo, D., \& Muhfizar. (2017). Studi Eksperimen untuk Kondisi Tanpa Beban pada Pengering Ikan Tipe Greenhouse Aktif, 6(2), 43-47.

45. Sobukola, O. P., \& Olatunde, S. O. (2011). Effect of salting techniques on salt uptake and drying kinetics of African catfish (Clarias gariepinus). Food and Bioproducts Processing, 89(3), 170-177. https://doi.org/10.1016/j.fbp.2010.06.002.

46. Sonmete, M. H., Mengeş, H. O., Ertekin, C., \& Özcan, M. M. (2017). Mathematical modeling of thin layer drying of carrot slices by forced convection. Journal of Food Measurement and Characterization, 11(2), 629-638. https://doi.org/10.1007/s11694-0169432-y.

47. Taheri-garavand, A., Rafiee, S., \& Keyhani, A. (2011). Mathematical Modeling of Thin Layer Drying Kinetics of Tomato Influence of Air Dryer Conditions. International Transaction Journal of Engineering, Management, \& Applied Sciences \& Technologies, 2(2), 147-160.

48. Taheri-Garavand, A., Rafiee, S., \& Keyhani, A. (2011). Study on effective moisture diffusivity, activation energy and mathematical modeling of thin layer drying kinetics of bell pepper. Australian Journal of Crop Science, 5(2), 128-131.

49. Tahmasebi, A., Yu, J., \& Han, Y. (2013). A kinetic study of microwave and fluidized-bed drying of a. Chemical Engineering Research and Design, 2(February), 1-12. https://doi.org/10.1016/j.cherd.2013.06.013.

50. Vijayan, S., Arjunan, T. V., \& Kumar, A. (2016). Mathematical modeling and performance analysis of thin layer drying of bitter gourd in sensible storage based indirect solar dryer. Innovative Food Science and Emerging Technologies, 36, 59-67. https://doi.org/10.1016/j.ifset.2016.05.014. 